\title{
Photoelectrochemical studies on aqueous suspensions of some nanometal oxide/chalcogenide semiconductors for hydrogen production
}

\author{
KASEM K KASEM* and AUBREY FINLEY \\ School of Sciences, Indiana University Kokomo, Kokomo, IN 46904, USA
}

MS received 1 April 2013; revised 18 September 2013

\begin{abstract}
Photoproduction of hydrogen was achieved by photolysis of aqueous suspensions of mixed $\mathrm{TiO}_{2} / \mathrm{V}_{2} \mathrm{O}_{5}$ or $\mathrm{CdS} / \mathrm{ZnS}$ semiconductor $(\mathrm{SC})$ nanoparticle in phosphate buffers containing $\left[\mathrm{Fe}(\mathrm{CN})_{6}\right]^{4-}$. Manipulations of the band structure of the SC materials took place by either combining oxides/sulphides in binary mixtures or by modification of the SC surface with an organic semiconductor. Studies show that the bandgap of these mixed materials varied monotonically with the percent composition of the mixture. Furthermore, results show that maximum generation of hydrated electrons by $\left[\mathrm{Fe}(\mathrm{CN})_{6}\right]^{4-}$ occurred at $\mathrm{pH}$ 6. Mixtures of $\mathrm{CdS} / \mathrm{ZnS}$ showed greater photoactivity than metal oxides $\mathrm{TiO}_{2} / \mathrm{V}_{2} \mathrm{O}_{5}$. On the other hand, surface-modified $\mathrm{CdS}$ or $\mathrm{TiO}_{2}$ gave much better photoreduction than the high percentage composite mixtures. The aqueous nanosystems used in these studies sustained their stability as indicated by the reproducibility of their photocatalytic activities.
\end{abstract}

Keywords. Photoelectrochemical; nanomaterial; suspensions; hydrogen; oxides; chalcogenides.

\section{Introduction}

Photolysis of water using some semiconductor (SC) mediators for generation of hydrogen and oxygen was reported by several researchers. ${ }^{1-8}$ Nano-sized metal chalcogenides such as sulphides, selenides and tellurides with specific bandgaps that can serve this purpose are being produced following a variety of procedures. ${ }^{9-15}$ The photocurrent obtained using such nano-sized assemblies is often low because fast charge recombination limits photocurrent generation. When composite semiconductors are used it is possible to improve the efficiency of charge separation through charge rectification. This can take place by modifying either the surface of the base semiconductor or its composition with either inorganic or organic semiconductors.

In some studies, nano-size semiconductors were used because of their larger surface area and their ability to carry out all the reactions that were previously associated with semiconductor electrodes. $\mathrm{TiO}_{2}$ (Titania) is known as a photocatalysis agent for a wide range of substances. ${ }^{16}$ Nano-sized $\mathrm{TiO}_{2}$ possesses enhanced photocatalytic activity and solar energy conversion. ${ }^{17,18}$ However, some disadvantages limit the efficient use of $\mathrm{TiO}_{2}$. For example, the high bandgap energy $(3.2 \mathrm{eV})$ requires UV radiation for photoactivation, limiting its application in the visible light range, and charge carrier recombination $\left(\mathrm{e}^{-} / \mathrm{h}^{+}\right)$occurs within nanoseconds limiting its photocatalytic activity. ${ }^{19}$ The spatial separation between oxidative and reductive sites is very small and increases the occurrence of back reactions.

*Author for correspondence (kkasem@iuk.edu)
Charge separation and exchange at the interface between semiconductor/electrolytes interface can be enhanced by doping the metal oxide or chalcogenides with another metal. Such doping or mixing alters the energy band structure of the doped oxides or chalcogenides, and consequently alters the donor/acceptor character of the assemblies. Recent studies show that binary oxides can provide more efficient charge separation, increased lifetime of charge carriers and enhanced interfacial charge transfer to absorbed substrates. ${ }^{20}$ Studies have been conducted on the photocatalytic activity using the binary semiconductor oxide system such as $\mathrm{TiO}_{2} / \mathrm{SnO}_{2}, \mathrm{TiO}_{2} / \mathrm{ZrO}_{2}, \mathrm{TiO}_{2} / \mathrm{MoO}_{3}$, $\mathrm{TiO}_{2} / \mathrm{CdS}, \mathrm{TiO}_{2} / \mathrm{Fe}_{2} \mathrm{O}_{3}, \mathrm{TiO}_{2} / \mathrm{WO}_{3}, \mathrm{CdS} / \mathrm{ZnO}, \mathrm{CdS} / \mathrm{AgI}$ and $\mathrm{ZnO} / \mathrm{ZnS}{ }^{20,21}$ The effects of doping metal oxides with another metal oxide was explained in some systems by the creation of oxygen vacancies in the lattice of the studied assembly structures. ${ }^{22}$

CdS has been intensively studied as a model for widely used metal chalcogenides due to several advantages such as its bandgap energy in the visible region $E_{\mathrm{g}}=2.5 \mathrm{eV}$ and its relatively simple fabrication process. CdS nanoparticles often present novel properties and have been widely used in solar cells, optoelectronics and microelectronics. CdS particles form a group of direct bandgap materials suitable for light-emitting applications, and their luminescent properties have been studied extensively. ${ }^{23}$ The small size of nanoparticles leads to their larger surface area. This will increase the number of surface-specific active sites for both chemical reactions and photon absorption. When particle size decreases below the Bohr radius of the first excitation state, quantum size effects can occur due to the confinement of the charge carriers. ${ }^{24}$ 
Although the stability conditions are not met by $\mathrm{CdS}$, because its decomposition potential $\left(E_{\mathrm{p}, \mathrm{d}}\right)$ is less than the oxidation potential of water $\left(E_{\mathrm{O}_{2} / \mathrm{H}_{2} \mathrm{O}}\right)$, its reduction potential is more negative than that of $\mathrm{H}^{+}$. Mixing $\mathrm{CdS}$ and $\mathrm{ZnS}$ by codeposition may push the limits of the $\mathrm{CdS} / \mathrm{ZnS}$ band structure to the level where the decomposition potential is greater than that of the decomposition of water. Mixtures of $\mathrm{CdS} / \mathrm{ZnS}$ and $\mathrm{Zr}$ phosphates were used for photolysis of water for hydrogen production. ${ }^{25,26}$

Effective conversion of solar energy to hydrogen content requires an inexpensive source that contains hydrogen and has a large surface area. Aqueous colloidal nanoparticle suspensions meet these requirements. The suspension media are equally as important as the suspension particles in generating an efficient photolysis process. Previous studies used semiconductor particles as major producers of photonic outcome through heterogeneous charge transfer processes at the particle/electrolyte interface. ${ }^{27,28}$ Hydrated electrons can play an important role in the photodissociation of water through these reactions:

$$
\begin{aligned}
& {\left[\mathrm{Fe}(\mathrm{CN})_{6}\right]^{4-}+h v=\left[\mathrm{Fe}(\mathrm{CN})_{6}\right]^{3-}+\mathrm{e}_{\mathrm{aq}^{-}}} \\
& \mathrm{e}_{\mathrm{aq}^{-}}+\mathrm{e}_{\mathrm{aq}^{-}}=\mathrm{H}_{2}+2 \mathrm{OH}^{-} \\
& 2\left[\mathrm{Fe}(\mathrm{CN})_{6}\right]^{4-}+2 h v=2\left[\mathrm{Fe}(\mathrm{CN})_{6}\right]^{3-}+\mathrm{H}_{2}+2 \mathrm{OH}^{-} .
\end{aligned}
$$

The molecular orbital structure of hexacyanoiron iron (II) $\left[\mathrm{Fe}(\mathrm{CN})_{6}\right]^{4-}$ allows electronic transitions under the photoexcitation condition and produces hydrated electrons that react according to the above reaction. $\left[\mathrm{Fe}(\mathrm{CN})_{6}\right]^{4-}$ undergoes oxidation to $\left[\mathrm{Fe}(\mathrm{CN})_{6}\right]^{3-}$. The disadvantage of a homogeneous process for hydrated electron production is its irreversibility. However, this disadvantage can be overcome by the use of a semiconductor system, which acts as an electron donor and reduces $\left[\mathrm{Fe}(\mathrm{CN})_{6}\right]^{3-}$ back to $\left[\mathrm{Fe}(\mathrm{CN})_{6}\right]^{4-}$. Achieving such a goal will create the conditions of reversible ergo-dynamics. The CdS bandgap can be expanded for efficient capture of UV-visible radiation by mixing it with $\mathrm{ZnS}$, which possesses a greater bandgap than $\mathrm{CdS}$. Furthermore, $\mathrm{TiO}_{2}$ bandgap can be altered to absorb a lower energy light wavelength by mixing it with lower bandgap $\mathrm{V}_{2} \mathrm{O}_{5}$ because $\mathrm{V}_{2} \mathrm{O}_{5}$ and CdS have a closer bandgap value of $2.4 \mathrm{eV}$, while $\mathrm{TiO}_{2}$ and $\mathrm{ZnS}$ have a comparable bandgap value of $3.1 \mathrm{eV}$. Mixing the two chalcogenides $\mathrm{ZnS}$ and $\mathrm{CdS}$ or the two oxides $\mathrm{TiO}_{2}$ and $\mathrm{V}_{2} \mathrm{O}_{5}$ would create either straddling or staggered gaps alignment of the energy band at the interface. This is due to the fact that both $\mathrm{V}_{2} \mathrm{O}_{5}$ and $\mathrm{CdS}$ have smaller bandgaps than either $\mathrm{TiO}_{2}$ or $\mathrm{ZnS}$. Furthermore, the conduction band of either $\mathrm{TiO}_{2}$ or $\mathrm{ZnS}$ is at more a negative potential than those of $\mathrm{V}_{2} \mathrm{O}_{5}$ and $\mathrm{CdS}$, respectively. With these similarities in band structure of assemblies, we expect that the oxide mixtures may give better photoactivities than chalcogenides mixture. In this paper we investigated the effects of adding $\mathrm{ZnS}$ to $\mathrm{CdS}$ in the mixed $\mathrm{CdS} / \mathrm{ZnS}$ composites, and adding of $\mathrm{V}_{2} \mathrm{O}_{5}$ to $\mathrm{TiO}_{2}$ in a mixture of $\mathrm{TiO}_{2} / \mathrm{V}_{2} \mathrm{O}_{5}$ on the photocatalytic behaviour of these mixture suspensions towards generation of hydrogen during the photolysis of buffered aqueous ferrocyanide solutions as hydrated electron suppliers.

\section{Experimental}

\subsection{Reagents}

All reagents were of analytical grade. All solutions were prepared using deionized water unless otherwise stated. CdS/ $\mathrm{ZnS}$ and $\mathrm{TiO}_{2} / \mathrm{V}_{2} \mathrm{O}_{5}$ composites were prepared as described elsewhere. ${ }^{29}$

\subsection{Instrumentation}

All electrochemical experiments were carried out using a conventional three-electrode cell consisting of Pt wire as a counter electrode, $\mathrm{Ag} / \mathrm{AgCl}$ as a reference electrode, and Pt gauze as an electron collector. A BAS 100-W electrochemical analyzer (Bioanalytical Co.) was used to carry out the electrochemical studies. Steady-state reflectance spectra were recorded using a Shimadzu UV-2101 PC.

\subsection{Photolysis cell}

The electrolysis cell was a $120-\mathrm{ml}$ one-compartment Pyrex cell with a quartz window facing the irradiation source. A $10-\mathrm{cm}^{2}$ platinum gauze cylinder was used as the working electrode. $\mathrm{A} \mathrm{Ag} / \mathrm{AgCl} / \mathrm{Cl}^{-}$reference electrode was also fitted into this compartment. A $10-\mathrm{cm}^{2}$ platinum counter electrode was housed in a glass cylinder sealed at one end with a fine-porosity glass frit. The $\mathrm{pH}$ was adjusted by the

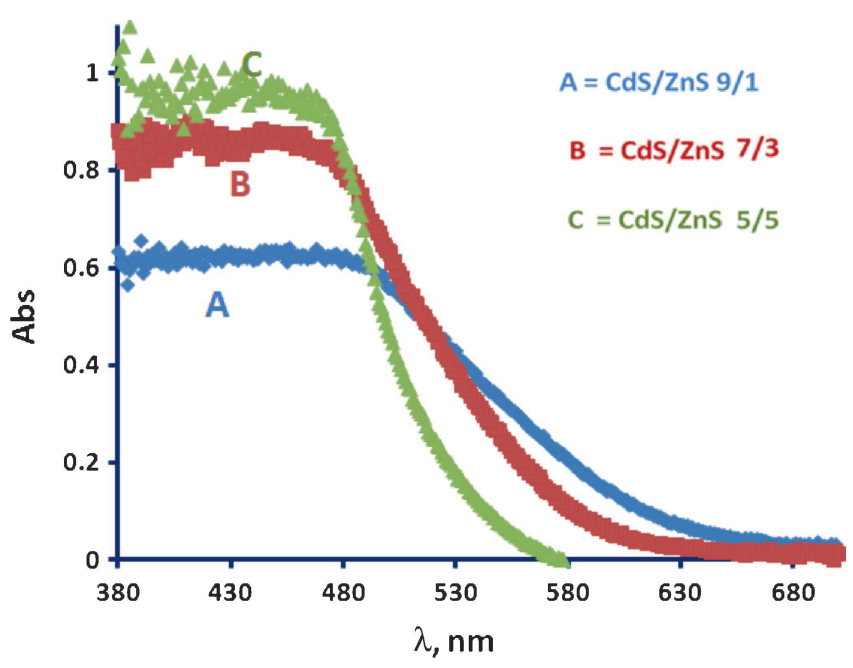

Figure 1. Diffusive reflectance absorption spectra of $\mathrm{CdS} / \mathrm{ZnS}$ nanoparticle composites. 
addition of either $1 \mathrm{M} \mathrm{NaOH}$ or $1 \mathrm{M} \mathrm{HNO}_{3}$. Aqueous suspensions were stirred with a magnetic stirrer during the measurements. Details of the photolysis cell and operation were as described elsewhere. ${ }^{30}$

\section{Results and discussion}

\subsection{Energy map of CdS/ZnS composite}

Figure 1 illustrates the diffusive reflectance absorption spectra of $\mathrm{CdS} / \mathrm{ZnS}$ nanoparticle composites. Analysis of the data provided by this figure, using Tauc equations, ${ }^{31}$ indicates that the studied $\mathrm{CdS} / \mathrm{ZnS}$ mixtures possess a direct and an indirect bandgaps. Figure 2 shows that these bandgaps varied monotonically with the percent compositions of $\mathrm{ZnS}$ and of $\mathrm{CdS}$. The fact that the absorption of the mixture extended into the

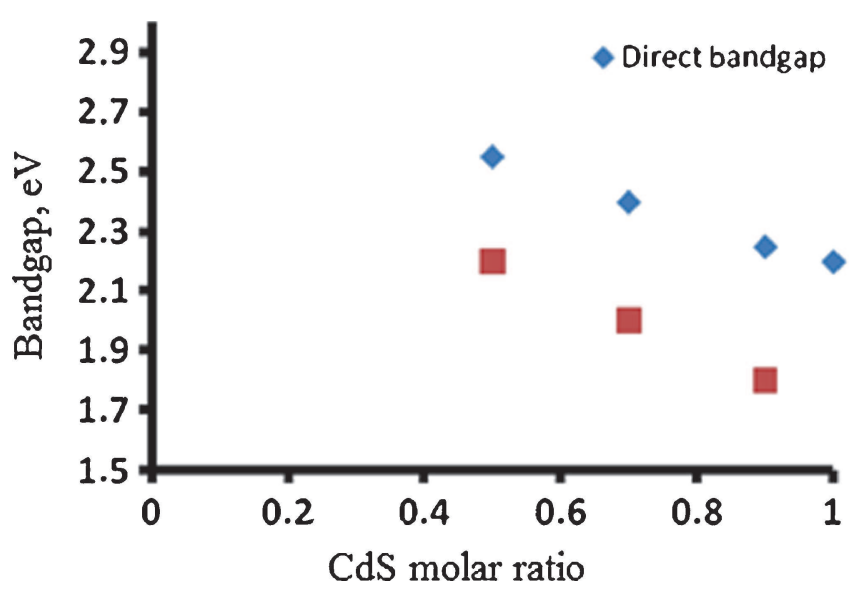

Figure 2. Direct and indirect bandgaps for $\mathrm{CdS} / \mathrm{ZnS}$ composites.

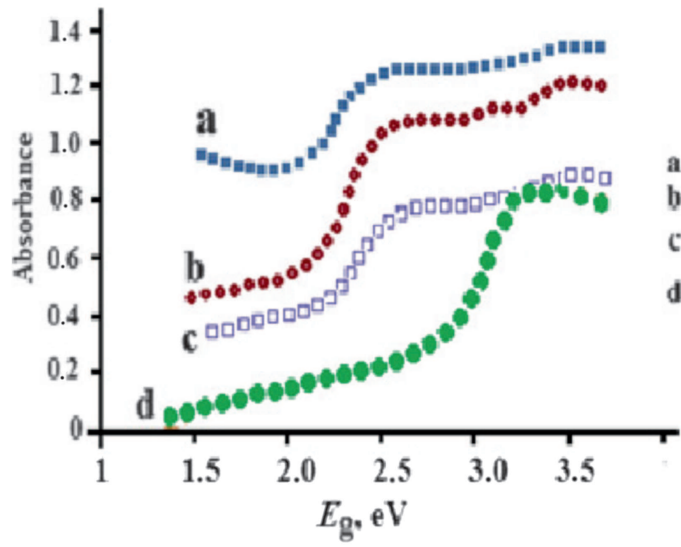

(A)

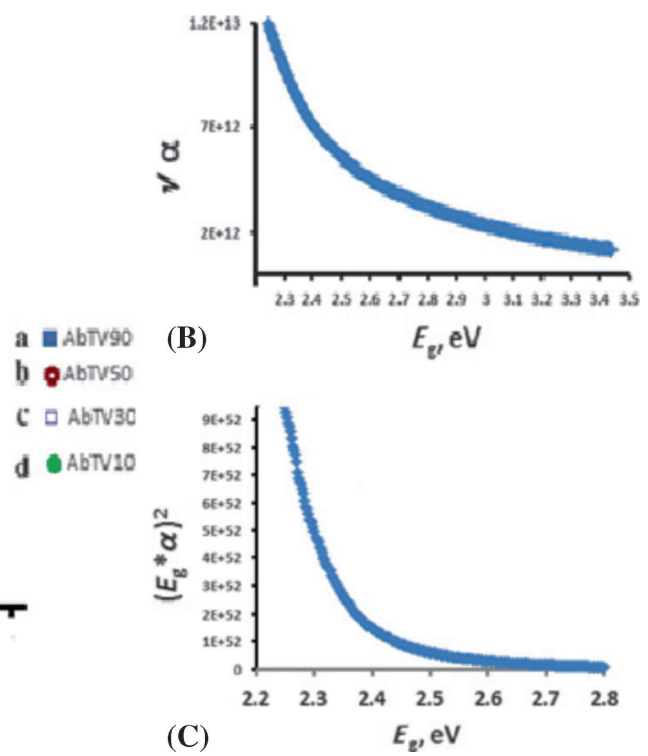

UV (ca. $380 \mathrm{~nm}$ ) indicates the conduction band exhibits only small shifts, while the majority of the bandgap change is due to an upward shift of the valence band.

\subsection{Energy map of $\mathrm{TiO}_{2} / \mathrm{V}_{2} \mathrm{O}_{5}$ composite}

Figure 3 illustrates the diffusive reflectance absorption spectra of $\mathrm{TiO}_{2} / \mathrm{V}_{2} \mathrm{O}_{5}$ nanoparticle composites. Analysis of the data in this figure, using Tauc equations, indicates that the studied $\mathrm{TiO}_{2} / \mathrm{V}_{2} \mathrm{O}_{5}$ mixtures possess both a direct and an indirect bandgaps. Table 1 shows that these bandgaps varied monotonically with the percent compositions of $\mathrm{V}_{2} \mathrm{O}_{5}$ up to $50 \%$. The fact that the absorption of the mixture extended more into the visible region indicates that the $\mathrm{V}(\mathrm{V})$ ions altered the surface states of the mixture.

\subsection{Photolysis of aqueous solutions of $\mathrm{K}_{\mathbf{4}}\left[\mathrm{Fe}(\mathrm{CN})_{6}\right]$}

3.3a Effect of the $p H$ : One of the products of reaction 3 is $\mathrm{OH}^{-}$, which makes this reaction $\mathrm{pH}$ dependent. This reaction product suggests that an acid $\mathrm{pH}$ range would be suitable to shift its equilibrium to favour $\mathrm{H}_{2}$ production. However, $\mathrm{K}_{4}\left[\mathrm{Fe}(\mathrm{CN})_{6}\right]$ as a reactant is $\mathrm{pH}$ sensitive. We

Table 1. Bandgap data for $\mathrm{TiO}_{2} / \mathrm{V}_{2} \mathrm{O}_{5}$ mixtures.

\begin{tabular}{lccc}
\hline $\begin{array}{l}\mathrm{V}_{2} \mathrm{O}_{5} \% \text { in } \mathrm{TiO}_{2} / \\
\mathrm{V}_{2} \mathrm{O}_{5} \text { mixtures }\end{array}$ & $\begin{array}{c}\text { Bandgap, } \\
\text { eV }\end{array}$ & $\begin{array}{c}\text { Direct band- } \\
\text { gap, eV }\end{array}$ & $\begin{array}{c}\text { Indirect band- } \\
\text { gap, eV }\end{array}$ \\
\hline 0.0 & 3.2 & 3.2 & \\
10 & 3.1 & 2.65 & 2.9 \\
30 & 3.0 & 2.60 & 2.7 \\
50 & 2.45 & 2.45 & 2.60 \\
90 & 2.38 & 2.40 & 2.55 \\
\hline
\end{tabular}

Figure 3. (A) Steady-state reflectance spectra for $\mathrm{TiO}_{2} / \mathrm{V}_{2} \mathrm{O}_{5}$ mixtures and (B, C) Tauc plots for indirect and direct bandgap $\mathrm{TiO}_{2} / \mathrm{V}_{2} \mathrm{O}_{5}$ (50/50) mixture. 


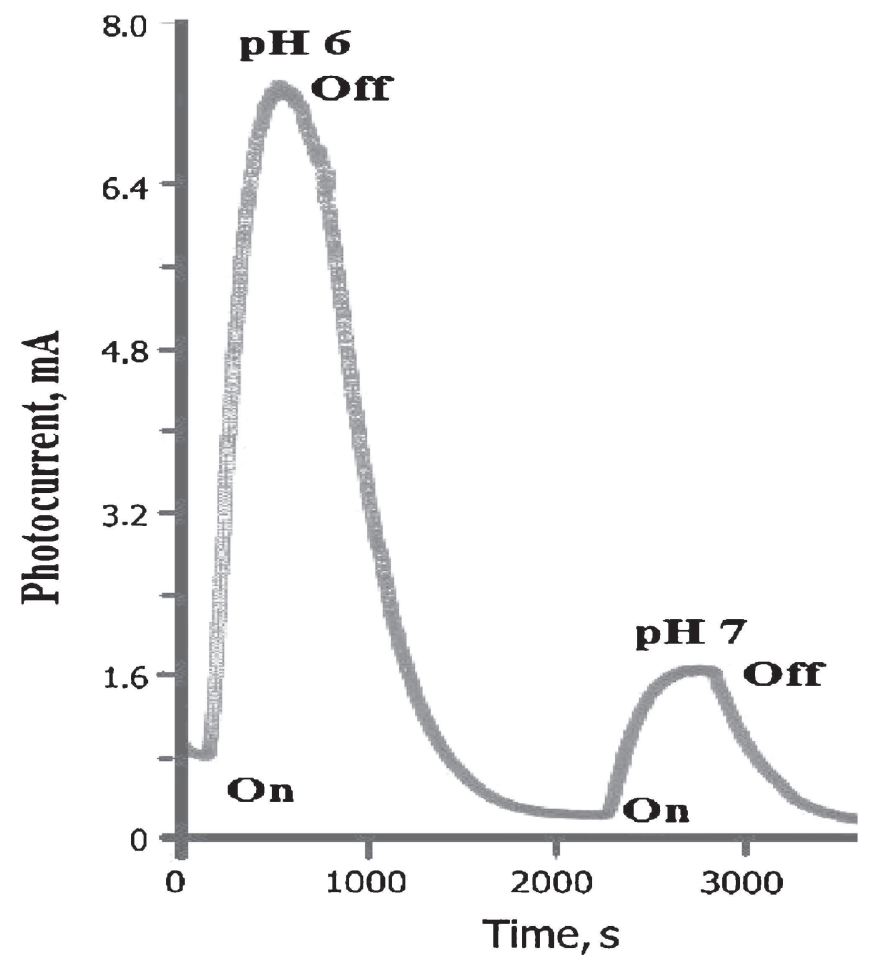

Figure 4. Effect of $\mathrm{pH}$ change on measured photocurrent.

have found that at $\mathrm{pH}$ less than $6, \mathrm{~K}_{4}\left[\mathrm{Fe}(\mathrm{CN})_{6}\right]$ will form a green compound known as Berlin green or ferric ferrocyanide, $\mathrm{Fe}_{3}\left[\mathrm{Fe}(\mathrm{CN})_{6}\right]_{4}$. Photolysis of aqueous $\mathrm{K}_{4}\left[\mathrm{Fe}(\mathrm{CN})_{6}\right]$ in phosphate buffers at different $\mathrm{pH}$ values were performed. The results are displayed in figure 4, from which we can notice a drop in photocurrent at $\mathrm{pH}$ greater than 6 . For these reasons, photolysis of aqueous $\mathrm{K}_{4}\left[\mathrm{Fe}(\mathrm{CN})_{6}\right]$ in the presence of nano-mixture nanoparticles was conducted at $\mathrm{pH} 6$.

3.3b Photolysis of aqueous $\mathrm{K}_{4}\left[\mathrm{Fe}(\mathrm{CN})_{6}\right]$ in the presence of CdS/ZnS suspensions: Aqueous suspensions of pure CdS in $0.2 \mathrm{M}$ phosphate buffer at $\mathrm{pH} 6$ containing $10 \mathrm{mmol}$ of $\mathrm{K}_{4}\left[\mathrm{Fe}(\mathrm{CN})_{6}\right]$ were subject to the photolysis process. The potential of the Pt collector electrode was kept constant at $0.000 \mathrm{~V} v s . \mathrm{Ag} / \mathrm{AgCl}$. The results are displayed in figure 5. The recorded photocurrent in figure 5 is due to the electrochemical reduction of $\mathrm{K}_{3}\left[\mathrm{Fe}(\mathrm{CN})_{6}\right]$. In the presence of illuminated $\mathrm{CdS}$, reduction of $\mathrm{K}_{3}\left[\mathrm{Fe}(\mathrm{CN})_{6}\right]$ can take place by an electrochemical and/or by a photochemical process. The collector electrode records only the electrochemical process. The amount of $\mathrm{K}_{3}\left[\mathrm{Fe}(\mathrm{CN})_{6}\right]$ reduced by the photochemical process can be estimated by the difference between the current recorded for the photolysis of $\mathrm{K}_{4}\left[\mathrm{Fe}(\mathrm{CN})_{6}\right]$ and at $\mathrm{pH}$ 6 in the absence and in the presence of SC according to the following equation:

Photoreduction current $I_{\text {photored }}=I_{\text {red }}$ in the absence of

$$
\mathrm{SC}-I_{\text {red }} \text { in the presence of SC. }
$$

It can be noticed that the recorded $I_{\text {red }}$ in the presence of SC (figure 5) is less than that recorded for $10 \mathrm{mmol}$ of

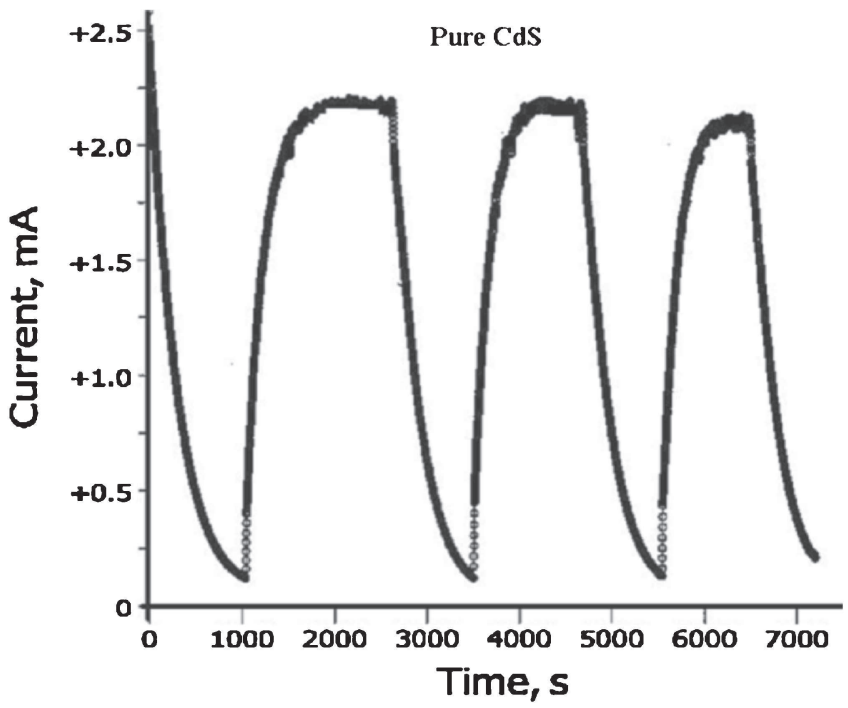

Figure 5. Photoelectrochemical response of working electrode during the photolysis of aqueous suspensions of pure CdS nanoparticles containing $10 \mathrm{mM}$ of $\left.\mathrm{Fe}(\mathrm{CN})_{6}\right]^{4-}$.

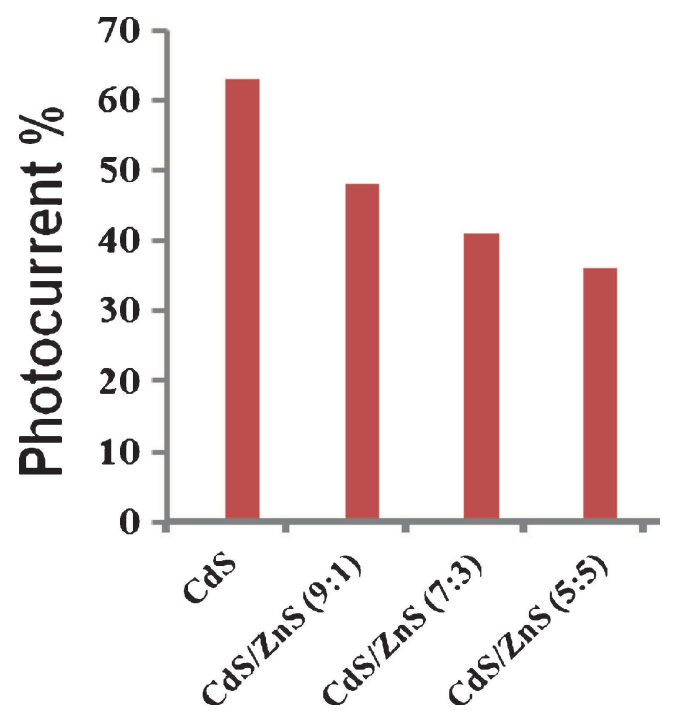

Figure 6. Effect of $\mathrm{ZnS}$ percentage on the reduction of $\left.\mathrm{Fe}(\mathrm{CN})_{6}\right]^{3-}$ in $\mathrm{pH} 6$ phosphate buffer.

$\mathrm{K}_{4}\left[\mathrm{Fe}(\mathrm{CN})_{6}\right]$ only (figure 4). Furthermore, the recorded current is reproducible at almost constant values, indicating that CdS particles maintained their stability against photodeterioration.

Photolysis of $10 \mathrm{mM}$ of $\mathrm{K}_{4}\left[\mathrm{Fe}(\mathrm{CN})_{6}\right]$ containing $\mathrm{CdS} / \mathrm{ZnS}$ nanocomposites in $0.2 \mathrm{M}$ phosphate buffer at $\mathrm{pH} 6$ took place under conditions similar to those for CdS. The effect of $\mathrm{ZnS}$ concentration on the measured photocurrent can be noticed from figure 6. As the percentage of $\mathrm{ZnS}$ increases, the reduction of $\left[\mathrm{Fe}(\mathrm{CN})_{6}\right]^{3-}$ decreases according to the following equation:

$$
\left[\mathrm{Fe}(\mathrm{CN})_{6}\right]^{3-}+h v+(\mathrm{e} / \mathrm{h})=\left[\mathrm{Fe}(\mathrm{CN})_{6}\right]^{4-}+\mathrm{e}_{\mathrm{aq}^{-}} .
$$


Table 2. Steady-state photocurrent for studied metal oxide nanoparticles at $\mathrm{pH} 6$ in $20 \mathrm{mM} \mathrm{K} 4\left[\mathrm{Fe}(\mathrm{CN})_{6}\right]$ at $-100 \mathrm{mV}$ vs. $\mathrm{Ag} / \mathrm{AgCl}$ electrode.

\begin{tabular}{lccccc}
\hline $\begin{array}{l}\text { \% of } \mathrm{V}_{2} \mathrm{O}_{5} \\
\text { in } \mathrm{TiO}_{2}\end{array}$ & $\begin{array}{c}I_{\mathrm{EC}}, \mathrm{mA} \text { in } \\
{\left[\mathrm{Fe}(\mathrm{CN})_{6}\right]^{4-}}\end{array}$ & $\begin{array}{c}I_{\mathrm{EC}}, \mathrm{mA} \text { in } \\
{\left[\mathrm{Fe}(\mathrm{CN})_{6}\right]^{4-}+\text { oxides }}\end{array}$ & $\begin{array}{c}I_{\text {photo }}, \mathrm{mA} \\
\text { due to oxides }\end{array}$ & $\begin{array}{c}\text { \% } I_{\text {photo }} \text { due to } \\
\text { oxides only }\end{array}$ & $\begin{array}{c}\text { Steady-state } \mathrm{H}_{2} \text { production, } \\
\mathrm{mol} \mathrm{h}^{-1} \mathrm{~m}^{-2}\end{array}$ \\
\hline 10 & 5.76 & 4.42 & 1.34 & 23.6 & 0.0250 \\
30 & 5.39 & 3.39 & 2.00 & 37.1 & 0.0373 \\
$\mathrm{Bandgap}, \mathrm{eV}$ \\
90 & 5.85 & 3.07 & 2.78 & 47.5 & 0.0519 \\
\hline
\end{tabular}

$\mathrm{EC}=$ electrochemical
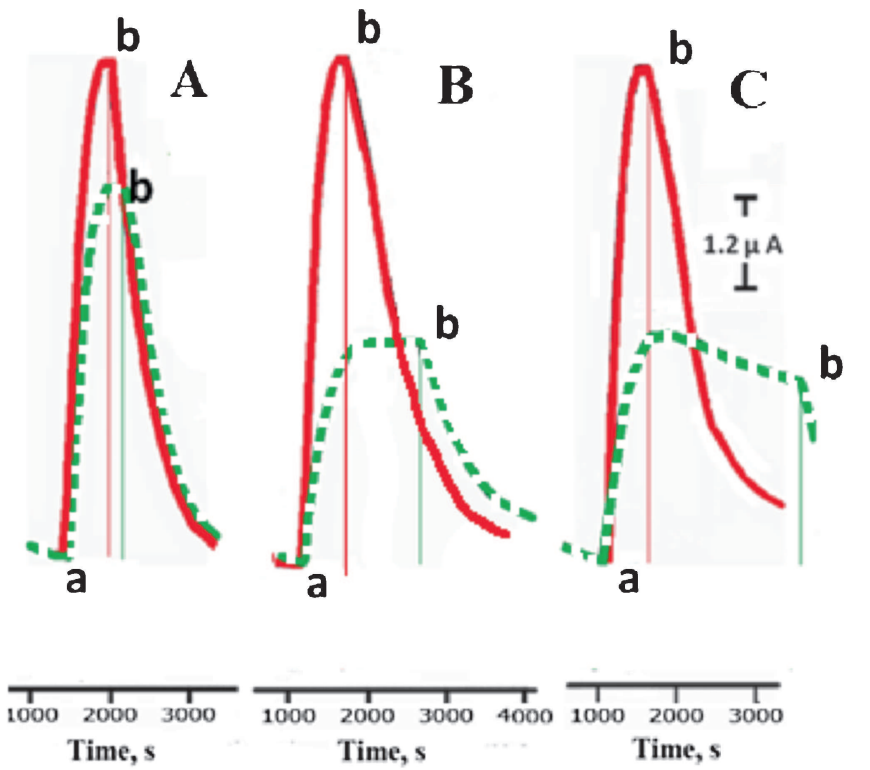

Figure 7. Photoelectrochemical response of working electrode during the photolysis of colloidal nanoparticles of $\mathrm{TiO}_{2}$ doped with $\mathrm{V}_{2} \mathrm{O}_{5}$ in $20 \mathrm{mM}$ of $\mathrm{K}_{4}\left[\mathrm{Fe}(\mathrm{CN})_{6}\right]$ in $0.2 \mathrm{M}$ phosphate buffer ( $\mathrm{pH}=6$ ). (A) $\mathrm{TiO}_{2}$ doped with $10 \% \mathrm{~V}_{2} \mathrm{O}_{5}$, (B) $\mathrm{TiO}_{2}$ doped with $50 \% \mathrm{~V}_{2} \mathrm{O}_{5}$ and $(\mathbf{C}) \mathrm{V}_{2} \mathrm{O}_{5}$ doped with $10 \% \mathrm{TiO}_{2}$, points a and $\mathrm{b}$ refer to illumination and dark, respectively.

Such behaviour is expected because the addition of large bandgap material such as $\mathrm{ZnS}$ to $\mathrm{CdS}$ will expand the bandgap of the resulting mixture. The expanded bandgap will respond only to shorter wavelengths of low intensity.

\subsection{Photolysis of aqueous $K_{4}\left[\mathrm{Fe}(\mathrm{CN})_{6}\right]$ in the presence of $\mathrm{TiO}_{2} / \mathrm{V}_{2} \mathrm{O}_{5}$ suspensions}

Photolysis of aqueous suspensions of $\mathrm{TiO}_{2}$ mixed with 10, 30 and $50 \% \quad \mathrm{~V}_{2} \mathrm{O}_{5}$ and $\mathrm{V}_{2} \mathrm{O}_{5}$ mixed with $10 \% \quad \mathrm{TiO}_{2}$ took place as described in a process similar to that described during the photolysis of CdS/ZnS. The results are recorded in table 2 and figure 7. Table 2 indicates that the photoreduction of $\left[\mathrm{Fe}(\mathrm{CN})_{6}\right]^{3-}$ to $\left[\mathrm{Fe}(\mathrm{CN})_{6}\right]^{4-}$ caused by the oxide mixture nanoparticles increased with the increase in the percentage of $\mathrm{V}_{2} \mathrm{O}_{5}$ in the mixture. Such results are consistent with the decrease of the bandgap of $\mathrm{TiO}_{2}$ with the increase in the percentage of $\mathrm{V}_{2} \mathrm{O}_{5}$. Lowering the bandgap increases the absorption in the visible region of the solar spectrum and consequently increases the photoreduction by the $p$-type semiconductor. When $\mathrm{TiO}_{2}$ becomes the dopant in $\mathrm{V}_{2} \mathrm{O}_{5}\left(10 \% \mathrm{TiO}_{2}\right.$ with $\left.90 \% \mathrm{~V}_{2} \mathrm{O}_{5}\right)$, the photoreduction drops back slightly to a lower value than that of $50 \% \mathrm{~V}_{2} \mathrm{O}_{5}$.

The results displayed in figure 7 can be explained on the basis of $\mathrm{V}(\mathrm{V})$ effects on the band structure of the oxide mixtures. Briefly, two important observations that were reported in this work demonstrate the major effect of $\mathrm{V}_{2} \mathrm{O}_{5}$ : (1) a more efficient photoresponse was reported when nanoparticles of $\mathrm{TiO}_{2}$ doped with $\mathrm{V}_{2} \mathrm{O}_{5}$ were suspended in buffered $\left[\mathrm{Fe}(\mathrm{CN})_{6}\right]^{4-}$ (see figure 7C); (2) the reproducible reactivity of these aqueous suspensions for a longtime without deactivation reflects their stability against photocorrosion. Our studies ${ }^{30}$ indicated that $\mathrm{TiO}_{2}$ doped with $5 \% \mathrm{~V}_{2} \mathrm{O}_{5}$ gives the greatest effect in phosphate buffer. Vanadium $\left(\mathrm{V}^{5+}\right)$ facilitates the transfer of charge carriers at the interface because of alteration of the flat-band potential, and increases the absorption of incident light energy as a result of the increase in depletion layer width at the junction. ${ }^{32} \mathrm{~V}^{5+}$ also supplied a high density of states that lower the bandgap of $\mathrm{TiO}_{2}$ and changed its bandgap transition from direct to indirect transitions.

\subsection{Hydrogen production in the photolysis process}

The results displayed in tables 2 and 3, and in figure 5 indicate that $\left[\mathrm{Fe}(\mathrm{CN})_{6}\right]^{4-}$ is an excellent supplier of hydrated electrons, which produce hydrogen according to reaction 3 . The continuous presence of $\left[\mathrm{Fe}(\mathrm{CN})_{6}\right]^{4-}$ will insure the generation of hydrated electrons and, consequently, hydrogen. Rates of hydrogen production via regeneration of $\left[\mathrm{Fe}(\mathrm{CN})_{6}\right]^{4-}$ by photochemical reduction of $\left[\mathrm{Fe}(\mathrm{CN})_{6}\right]^{3-}$ at semiconductor surfaces are listed in tables 2 and 3 . The data listed in table 2 indicate that increasing the percentage of $\mathrm{V}_{2} \mathrm{O}_{5}$ the photoreduction rate (and also hydrogen production rate) increases. On the other hand, the data listed in table 3 indicate that pure $\mathrm{CdS}$ generated the greatest rate among the studied mixtures. As the percentage of $\mathrm{ZnS}$ increases, the rate of hydrogen production decreases. 
Table 3. Hydrogen production rate during the photolysis process of $\left[\mathrm{Fe}(\mathrm{CN})_{6}\right]^{4-}$ in the aqueous suspensions of the studied nanoparticles.

\begin{tabular}{lccccc}
\hline $\begin{array}{l}\text { Semiconductor } \\
\text { composition }\end{array}$ & $\begin{array}{c}I_{\mathrm{EC}}, \mathrm{mA} \text { in } \\
{\left[\mathrm{Fe}(\mathrm{CN})_{6}\right]^{4-}}\end{array}$ & $\begin{array}{c}I_{\mathrm{EC}}, \mathrm{mA} \text { in } \\
{\left[\mathrm{Fe}(\mathrm{CN})_{6}\right]^{4-}+\text { sulphides }}\end{array}$ & $\begin{array}{c}I_{\text {photo }}, \mathrm{mA} \text { due } \\
\text { to sulphides }\end{array}$ & $\begin{array}{c}\% I_{\text {photo }} \text { due to } \\
\text { sulphides only }\end{array}$ & $\begin{array}{c}\text { Steady-state } \mathrm{H}_{2} \\
\text { production, } \mathrm{mol} \mathrm{h}^{-1} \mathrm{~m}^{-2}\end{array}$ \\
\hline Pure CdS & 6.09 & 2.664 & 3.431 & 56.2 & 0.0676 \\
CdS/ZnS 9:1 & 6.09 & 3.092 & 2.765 & 45.3 & 0.0546 \\
CdS/ZnS 7:3 & 6.09 & 3.426 & 2.669 & 43.8 & 0.0341 \\
CdS/ZnS 5:5 & 6.09 & 3.521 & 2.097 & 34.4 & 0.0316 \\
\hline
\end{tabular}

\section{Conclusion}

Mixed $\mathrm{CdS} / \mathrm{ZnS}$ or $\mathrm{TiO}_{2} / \mathrm{V}_{2} \mathrm{O}_{5}$ semiconductor materials were prepared and subjected to spectroscopic, electrochemical and photochemical characterization. Studies show that the direct bandgap of mixed nanomaterials varied monotonically with the percent of either $\mathrm{ZnS}$ or $\mathrm{V}_{2} \mathrm{O}_{5}$ in the mixture. Photolysis of $\left[\mathrm{Fe}(\mathrm{CN})_{6}\right]^{4-}$ in aqueous suspensions of nanoparticles is more efficient at $\mathrm{pH}$ 6. At higher $\mathrm{pHs}$ the electrochemical reduction process for $\left[\mathrm{Fe}(\mathrm{CN})_{6}\right]^{3-}$ decreases noticeably, while at lower $\mathrm{pH}$, formation of Berlins-Green complex was observed. The amount of $\left[\mathrm{Fe}(\mathrm{CN})_{6}\right]^{3-}$ reduced via the photochemical process decreased by increasing $\mathrm{ZnS}$ content in the $\mathrm{CdS} / \mathrm{ZnS}$ mixture (table 3), and increases with increasing $\mathrm{V}_{2} \mathrm{O}_{5}$ (upto 50\%) in $\mathrm{TiO}_{2} / \mathrm{V}_{2} \mathrm{O}_{5}$ (table 2) mixtures. Pure CdS generated the greatest photochemical production of hydrogen, compared with its mixtures with $\mathrm{ZnS}$. The data listed in tables 2 and 3 indicate that the sulphide mixtures were more effective in the hydrogen production than the oxides. Such results cannot be interpreted on the basis of the bandgap value, but rather on the efficient band alignments for each of the mixture components. The reproducibility of the photocatalytic activities of the studied nanoparticle mixtures is an indication that these systems retained their stability under illumination conditions. Other than stability factors, our results indicate that bandgap manipulations were an important factor in the photochemical activities of the tested composites of mixed chalcogenide and oxide nanoparticles.

\section{References}

1. Tabata S, Nishida H, Masaki Y and Tabata K 1995 Catal. Lett. 34245

2. Jang J S, Kim H G, Reddy V R, Bae S W, Ji S M and Lee J S 2005 J. Catal. 231213

3. Maeda K, Teramura K, Lu D, Saito N, Inoue Y and Domen K 2006 Angew. Chem. Int. Ed. 457806

4. Ryu S Y, Choi J, Balcerski W, Lee T K and Hoffmann M R 2007 Ind. Eng. Chem. Res. 467476

5. Blumstengel S, Koch N, Sadofev S, Schafer P, Johnson H R, Rabe J P and Henneberger F 2008 Appl. Phys. Lett. 92193303

6. Zhang Y J, Yan W, Wu Y P and Wang Z H 2008 Mater. Lett. 623846
7. Kasem K 2010 J. Mater. Sci. Technol. 26619

8. Mahesh A 2011 J. Nanomater. 921

9. Liu D and Kamat P V 1993 J. Phys. Chem. 9710769

10. Vogel R, Hoyer P and Weller H 1994 J. Phys. Chem. 983183

11. Plass R, Pelet S, Krueger J, Gratzel M and Bach U 2002 J. Phys. Chem. B 1067578

12. Peter L M, Wijayantha K G U, Riley D J and Waggett J P 2003 J. Phys. Chem. B 1078378

13. Chen M, Tang Y, Li B and Luo L 2009 J. Nanosci. Nanotechnol. 91505

14. Khanna P K, More P, Shewate R, Beri R K, Viswanath A K, Singh V and Mehta B R 2009 Chem. Lett. 38676

15. Park K, Yu H J, Chung W K, Kim B and Kim S H 2009 J. Mater. Sci. 444315

16. Peng T, Zhao D, Song H and Yan C 2005 J. Mol. Catal. A: Chem. 238119

17. Trapalis C C, Keivanidis P, Kordas G, Zaharescu M, Crisan M, Szatvanyi A and Gartner M 2003 Thin Solid Films 433186

18. Liao D L and Liao B Q 2007 J. Photochem. Photobiol. A: Chem. 187363

19. Saif M and Abdel-Mottaleb M S A 2007 Inorg. Chim. Acta $(\mathbf{9 , 1 0 )} 2863$

20. Wang C, Zhao J, Wang X, Mai B, Sheng G, Peng P and Fu J 2002 Appl. Catal. B: Environ. 39269

21. Liao D L, Badour C A and Liao B Q 2008 J. Photochem. Photobiol. A: Chem. 19411

22. Wang Y, Su Y R, Qiao L, Liu L X, Su Q, Zhu C Q and Liu X Q 2011 Nanotechnology 22225702

23. Hines M A and Guyton P S 1996 J. Phys. Chem. 100468

24. Serpone N, Lawless D and Pelizzetti E 1996 Fine particles science and technology Pelizzetti E (ed) (Kluwer Academics Publishers) p 657

25. Zhang J L, Xiao M, Liu Z M, Han B X, Jiang T and He J 2004 J. Colloid Interface Sci. 273160

26. Niranjan B, Das D P, Satyabadi M and Parida K M 2011 Int. J. Hydrogen Energy 3613452

27. Gordon S, Hars E J, Matheson M S, Rahani J and Thomas J K 1963 J. Am. Chem. Soc. 851375

28. Haque S A, Park T, Holmes A B and Durrant J R 2003 Chemphyschem: Eur. J. Chem. Phys. Phys. Chem. 489

29. Amma B S, Manzoor K, Ramakrishna K and Pattabi M 2008 Mater. Chem. Phys. 112789

30. Kasem K and Dahn M 2010 Curr. Sci. 991068

31. Van Leeuwen R A, Hung C-J, Kammler D R and Switzer J A 1998 J. Phys. Chem. 9915247

32. Saroj K, Chanakya T, Singh A P, Diwakar C, Rohit S, Sahab D and Vibha R S 2006 Curr. Sci. 911062 